\title{
Book review: Tomasz T. Aleksandrowicz, Terroryzm międzynarodowy [International Terrorism], Wydawnictwo Akademickie i Literackie, Warszawa 2015, pp. 198
}

\author{
Kamila REZMER, M.A. \\ Nicolaus Copernicus University, Toruń, Poland \\ kamila.rezmer@onet.pl
}

Terrorism represents an emotional response without a concrete strategic purpose, surprising by its spectacular nature and evoking fear. After every attack, it becomes a major topic in the media, undergoes numerous analyses and studies, and leads to debates on safety and attempts to create legal regulations that will enable effective counteraction. The phenomenon of terrorism is a very serious problem for the contemporary world, especially after recent attacks conducted by socalled ISIS fighters and so-called "lone wolves". The more sophisticated methods used, the more dangerous it becomes. Moreover, the progress of globalisation creates new conditions for action and contributes to the development of so-called cyberterrorism. Also, Europe touched by the "refugee crisis" is becoming an easy target for terrorists.

This undoubtedly important issue was addressed in a publication "International Terrorism", written by Tomasz R. Aleksandrowicz. The author is a professor of the Humanistic Academy in Pułtusk and the Higher School of Police in Szczytno. The issue of terrorism is not foreign to him because he worked in the analytical departments of the special services and in a Team of Advisers of the Chancellery of the President of the Republic of Poland as well. He has published over 100 scholarly publications including articles, books, e.g. "Security in the European 
Union" or "World on the Web: State - Society - People. In search of the New paradigm of scientific security".

The main content of the book is a reflection on the causes and the essence of terrorism, ways of preventing it, international legal regulations and forecasts of potential threats to Poland. In the first chapter entitled "The phenomenon of terrorism - theoretical findings", the history of the development of terrorism is introduced, which, for example, in Western civilisation goes back to the times of the French Revolution. The notion of terror also evolved according to historical circumstances. It can mean an excess of power, a tool of state policy or a tool to fight the state and its structures. Depending on the point of view, the term terrorist or freedom fighter has been defined differently. Among the sources of terrorism, the author mentions, in particular, poverty and poor economic development, and the simultaneous enrichment of elites, but also some disputes over nationalist, religious ideologies or quasi-religious sects. Anti-abortion movements, threats from single-issue terrorism and improved links between certain terrorist organisations and some organised crime groups are treated separately. Different disciplines of science define terrorism in other ways and they seek its sources in other places, but among these many definitions, one can distinguish certain common elements and qualities. For example, these is the use of violence or the threat of violence, the so-called blind crime, the development of a particular effect and reaction of the authorities or society, and the brutality of methods and their dynamics. An important tool for terrorists is the Internet. It is also possibile to talk about the media literacy of terrorism, which the author defines similarly as Kubicz does, as a set of traits that predispose to mass media popularity [p. 36]. From the times of Osama Bin Laden, Al-Qaeda and the "Islamic State", we are dealing with new terrorism. It is distinguished by the network nature of the organisations and religious motives. The author tries to make two points to show the difference between old and new types of terrorism. According to him, the essence of old terrorism was the coup itself, not the number of victims. It lacked the of focus on a mass. The risk of the terrorist dying has also been minimalised, which in the case of new terrorism becomes its inherent element [p. 52]. There is also a category of asymmetrical conflict, understood as the use of unconventional

1 https://www.civitas.edu.pl/pl/uczelnia/nasi-wykladowcy/dr-hab-tomasz-aleksandrowicz [accessed: 7.10.2017]. 
methods, means and tactics if there are disparities in military capabilities and other resources used in conflict and cultural diversity [p. 60].

The second chapter of the publication is entitled "International Laws Against Terrorism". It is worth noting that at first, terrorism was treated rather as a legal category than a political one. Conventions that have been established for many years under UNsupervision become sectoral in the absence of attemps to create a general definition of terrorism, because of the inclusion of only one of the terrorist sectors by applying the modus operandi criterion. These norms had the task of highlighting the terrorism, without defining its phenomenon. More generally, the European Convention on the Suppression of Terrorism was formed. The impulse for the creation of new, complementary and modified older regulations, was the attack on the World Trade Center and the Pentagon, and the fight against terrorism has become one of the main tasks of the European Union. Within the framework of the Council of Europe, the model for combatting terrorism was developed and solutions for fighting terrorism in modern international law began to be correlated. The definitions of terrorist acts have also been worked out.

The next chapter "Terrorism and War" distinguishes between terrorism and national liberation. The border is determined by the fact that the latter has no right to use terrorist methods. The author points out that we are also dealing with the term "war on terror", which began to function from the moment when Bush's political slogan was announced after the attacks of September 11, 2001. Thus it entered the dictionary of international political relations [pp. 112-113]. War on terror in this way is the kind of armed conflict that can be called an asymmetric one. In addition, there are numerous controversies over methods used in the war on terror and over the classification problems. The anti-terrorist campaign is under evaluation as a manifestation of the war on terror. The author discusses the changes in the understanding of the principles of the use of force under the Charter of the United Nations and the concept of responsibility for protection, that is ensuring respect for human rights and the responsibility for international communities in humanitarian disasters in the form of humanitarian intervention.

Chapter four of the publication is entitled "States Responsibilities in Combating Terrorism". It is pointed out that the essence of the international model for combatting terrorism relied on the principle of aut dedere aut iudicare, which is 
based on the principle of global repression and the duty of state cooperation, but with some exceptions. The problem arises when one is trying to define the concept of political offence as divergent from terrorism. Certain discrepancies also occur if the attack is considered a political offence. In the doctrine of international law, a distinction is made between a terrorist act and a political offence and a terrorist and a political offender. However, in positive international law, there is a lack of a binding norm in this area. With regard to the model for combatting international terrorism, the European Union has definied this cooperation in the EU Strategy. Another political and military organisation that obliges the Member States to respond to the crisis is NATO. The author defines this „as a forum for political cooperation between states and other international organisations in order to work out the common principles of action laid down in the Final Act of the Conference on Security and Co-operation in Europe, adopted in Helsinki in 1975" [p. 142]. In this chapter, the author identifies a significant problem with the fight against terrorism in relation to the respect for human rights, which includes both citizens' and terrorists.' There is also a collision of preventive measures with the right to privacy. Protection of human rights is guaranteed by the International Covenant on Civil and Political Rights and the European Convention for the Protection of Human Rights and Fundamental Freedoms. It is possible for Member States to evade the provisions of the Covenant only under strictly defined conditions. It was only recently that a thesis on human rights violations by terrorism was formulated and reflected in subsequent UN and OSCE documents. But, according to the author, the terrorists' rights must also be respected. The author uses the example of Al-Qaeda members' hearings and the European Court of Human Rights order to pay compensation to the government of the Republic of Poland [p. 149]. Later in this chapter, there appear some reflections on freedom and security, doubts about the right to privacy in the name of security, and the essence of liberal democracy. The author contemplates these in the context of the controversial Prüm Convention and its potential for establishing a new Direction in international law, and in the case of the United States and the debate on the Patriot Act, the Anti-Terrorism Act.

The last chapter deals directly with Poland and certain potential threats. It turns out that in 2004, Polish law lacked a normative definition of terrorism. Polish legislation used the term terrorism and terrorist offence only in the legal frame. The author seeks to formulate several elements of the terrorist threat forecasts, 
including the one that works perfectly today and speaks about more spectatular attacks, xenophobic reactions and the tightening of immigration policy [p. 169]. He also points out that Poland is for terrorists a "second choice target" as a result of Poland's limited importance on the international political scene and the threat will be strengthened and supported by examples.

The structure of the book is clear, the chapters are logically linked, and each of them closes the so-called "control block", where we will find keywords for this section of the publication, and questions related to the subject. All of this facilitates the reception of the book and assimilates its content. In addition, the most important definitions and explanations are highlighted in the text with phrases, which makes it posssible to return to the most interesting issues at any time. It clearly and simply presents the differences between, for example, terrorism and the national liberation struggle or new and old terrorism. The author's arguments and forecasts are supported by examples from both Poland and the world. He easily leads us through the intricate matter of international terrorism, starting with theoretical and historical background, through the law and with predictions about the Polish situation. The contents of the individual chapters of the publication are therefore justified by the objectives set out in its introduction. The regulations on combatting terrorism are clearly presented. This book is undoubtedly of great educational and cognitive value, but it is not without flaws.

Although in the introduction we read about the destination of this book as a textbook for a selected audience (including students) and thus as possessing scientific /value, inside we can find the use of the common and non-scientific categories with the flagship example - "leftist" (lewackie). The use of such terms implies the author's opinion, presentation of his attitude towards the issues discussed without warning the reader about the inclusion of these opinions, which is an unreliable practice in the field of described crafts. In addition,-the author points out how various scientists define the sources of terrorism. According to him, the researchers in the field of Political Science say that "the source of terrorism is the desire to change an existing situation that is objectively and/or subjectively unbearable and objectively and/or subjectively has no other way of making that change" [p. 26]. In this case, we are dealing with imprecise use of theoretical categories, because the tendency to change or preserve the status quo is in fact the basis of every political action, and therefore it is a necessary, but insufficient, 
condtition for developing a definition of terrorism (or any other political action). In politics, one should rather point out that "the political objectives of terrorism are closely related to its destructive influence on the authorities, its organs and representatives and thus on the destabilisation of social, economic and political life in the state" ${ }^{2}$ than only on the need for change. In a similar vein, other terrorism researchers, Daniel Heradsveit and David C. Pugh, point out the term "terrorist label" as the ultimate technique of delegitimisation ${ }^{3}$. They also point out that certain academic discussions, aimed at distinguishing terrorism from other forms of lethal policy, are pointless ${ }^{4}$. The only distingishing criterion that can be preserved and common for all acts and actors is to define the terrorist as an opponent ${ }^{5}$. The author incorretly uses numerical data, e.g. with regard to the table [p. 31] on the scale of terrorist threats in the years 2005-2014, where the author takes into account only the years 2012-2014 to justify changes during the period. In this case, he does not wonder and ask some questions about previous years, where in terms of the number of attacks and fatalities these numbers are similiar or even bigger. This proves inconsiderate use of data or their interpretation. On the other hand, modern terrorism indicates that its constant feature is the possibility of the perpetuator's death and wonders how it can threaten such a person. However, he gives no answer and the reader has a sense of hopelessness and weakness towards terrorists. He also polarises two positions, arguing that the response to terrorist threats violates the principles of a liberal democratic state, and that its absence contributes to the enlarged field of terrorism. This would mean that we are in a stalemate, where, on the one hand, our freedom is limited, and, on the other, it contributes to increasing the threat. The author does not seek an optimum solution where prevention would serve security and would not infringe on human rights and freedoms. The actions taken by the security services are considered burdensome and lead to the return of the state, which George Orwell created in one of his novels. However, the author is inconsistent here, because in the latter

2 S. Wojciechowski, Terroryzm na poczatku XXI wieku. Pojęcie, istota i przyczyny, zjawiska, Oficyna Wydawnicza Branta, Bydgoszcz-Poznań 2011, p. 71.

3 D. Heradstveit, D. C. Pugh, The Rhetoric of Hegemony: How to extend the definition of terrorism to redefine international relations, paper delivered at the International Conference „Rethinking Modernity: Globalisation, Modernization, Islam” held at MGIMO University in Moscow, October 23-26, 2003.

4 Ibid., p. 8.

5 Ibid., p. 13. 
part of the publication referring to another author, Stanisław Koziej, he seems to be justifying the prevention and taking up various activities and means. In the last chapter, he states that the choice between freedom and security is false and the threat is terror itself, not the person who escapes it.

Despite these few shortcomings, the book certainly deserves attention. However, it is important to be aware that the author is undertaking such widespread and extensively described subjects which do not show any particular innovation and communicate easily the state of the art of safety. Another position much more elaborate in this matter is the publication titled "Terrorism” by Wilhelm Dietl, Kai Hirschmann and Rolf Tophoven, published by PWN. It reveals the origins of terrorism and provides a careful analysis of the factors that influence the intensification or inhibition of this phenomenon, but also with the specificity of individual organisations. It may be a supplement to the reviewed publication.

Although the book was published in 2015, its content is perfectly reflected in the current very dynamic situation both in Poland and Europe. In particular, the forecasts of the last chapter concerning, among other things, the intensification of xenophobic behavior that we see today in Poland or the increasing spectacularness of the attacks, which is difficult to refute over the last two years. The position is also valuable in terms of teaching, especially for all kinds of teachings on security and disciplines such as internal security, national or international security. This position encourages the exploration of subjects and, for the scientists in the field of Political Science, is equally interesting from the perspective of effective state management, reflection on the essence of today's democracy and the question of the boundaries between ensuring security and the freedom of citizens or their right to privacy. It provides the readers with a comprehensive interpretation of the legal-international regulations that have an impact on the current practice of combatting terrorism. 


\section{Bibliography}

https://www.civitas.edu.pl/pl/uczelnia/nasi-wykladowcy/dr-hab-tomasz-aleksandrowicz [accessed: 7.10.2017]

Heradstveit, D., Pugh, D.C., The Rhetoric of Hegemony: How to extend the definition of terrorism to redefine international relations, paper delivered at the International Conference "Rethinking Modernity: Globalisation, Modernization, Islam" held at MGIMO University in Moscow, October 23-26, 2003.

Wojciechowski, S., Terroryzm na poczatku XXI wieku. Pojęcie, istota i przyczyny, zjawiska, Oficyna Wydawnicza Branta, Bydgoszcz-Poznań 2011. 